\title{
Antimicrobial and antioxidant activity of edible zein films incorporated with lysozyme, albumin proteins and disodium EDTA
}

\author{
Çiğdem Mecitoğlu Güçbilmez ${ }^{b}$, Ahmet Yemenicioğlu ${ }^{a, *}$, Alper Arslanoğlu ${ }^{c}$ \\ ${ }^{a}$ Department of Food Engineering, Faculty of Engineering, Izmir Institute of Technology, 35430 Gülbahçe Köyü, Urla, İzmir, Turkey \\ ${ }^{\mathrm{b}}$ Biotechnology and Bioengineering Program, Izmir Institute of Technology, 35430 Gülbahçe Köyü, Urla, İzmir, Turkey \\ ${ }^{\mathrm{c}}$ Department of Biology, Faculty of Science, Izmir Institute of Technology, 35430 Gülbahçe Köyü, Urla, İzmir, Turkey
}

Received 2 January 2006; accepted 26 August 2006

\begin{abstract}
In this study, partially purified lysozyme was incorporated into zein films in combination with chickpea albumin extract (CPAE), bovine serum albumin (BSA) and disodium EDTA. The zein films showed an inherent free radical scavenging activity. Incorporation of lysozyme did not contribute to soluble free radical scavenging activity of zein films. However, the incorporation of lysozyme in combination with CPAE increased the soluble and immobilized free radical scavenging activity of zein films $17 \%$ to $25 \%$ and almost $84 \%$, respectively. The incorporation of CPAE also improved the distribution of partially purified lysozyme preparation in zein films and enabled the controlled release of lysozyme by reducing its release rate from zein films between 1.5- and 3.5-fold, depending on the concentration of incorporated CPAE. In contrast, the BSA incorporation made distribution of lysozyme more heterogeneous and it did not contribute to the free radical scavenging activity of films significantly. The combinational incorporation of partially purified lysozyme with disodium EDTA $\cdot 2 \mathrm{H}_{2} \mathrm{O}$ or CPAE and disodium EDTA $\cdot 2 \mathrm{H}_{2} \mathrm{O}$ gave zein films effective on Escherichia coli and Bacillus subtilis. This study clearly showed the benefits of using functional protein extracts to control lysozyme distribution and release rate and to improve antioxidant activity in zein films.
\end{abstract}

(c) 2006 Elsevier Ltd. All rights reserved.

Keywords: Lysozyme; Edible films; Albumins; Antimicrobial packaging; Antioxidant activity

\section{Introduction}

The antimicrobial packaging is a rapidly developing technology that can be employed for controlling foodborne microbial outbreaks caused mainly by the easily prepared and minimally processed fresh produce (De Roever, 1998). Different antimicrobial chemicals such as organic or inorganic acids, metals, alcohols, ammonium compounds or amines can be incorporated into plastic, biodegradable and/or edible packaging materials (Appendini \& Hotchkiss, 2002; Suppakul, Miltz, Sonneveld, \& Bigger, 2003). However, due to the health concerns of the consumers and envi-

\footnotetext{
* Corresponding author. Tel.: +90 232 7506292; fax: +90 2327506196.

E-mail address: ahmetyemenicioglu@iyte.edu.tr (A. Yemenicioğlu).
}

ronmental problems, producers are now particularly interested in the use of biopreservatives such as antimicrobial enzymes and bacteriosins in edible and biodegradable packaging materials (Labuza \& Breene, 1989; Suppakul et al., 2003).

Lysozyme is one of the most frequently used antimicrobial enzymes incorporated into packaging materials (Appendini \& Hotchkiss, 1997; Buonocore et al., 2003; Cha, Choi, Chinnan, \& Park, 2002; Han, 2000; Mecitoğlu et al., 2006; Min, Harris, \& Krochta, 2005; Park, Daeschel, \& Zhao, 2004; Padgett, Han, \& Dawson, 1998; Quintavalla \& Vicini, 2002). This enzyme shows antimicrobial activity mainly on gram-positive bacteria by splitting the bonds between $N$-acetylmuramic acid and $N$-acetylglucosamine of the peptidoglycan in their cell walls. Because of their protective outer membrane surrounding the peptidoglycan 
layer, lysozyme does not show antibacterial activity against gram-negative bacteria. However, when it is combined with EDTA the outer membranes of gram-negative bacteria are destabilized by this agent and the antimicrobial spectrum of lysozyme increases significantly (Branen \& Davidson, 2004; Padgett et al., 1998). In studies related to antimicrobial films, most of the workers used commercial lysozyme obtained by the classical repeated salt crystallization method which may require a week until the enzyme is obtained with sufficient purity (Chang, Yang, \& Chang, 2000). The commonly used pure commercial lysozymes, reported to contain only $1-6 \%(\mathrm{w} / \mathrm{w})$ protein impurities (Judge, Forsythe, \& Pusey, 1998), have a very high enzyme activity (between 20000 and $100000 \mathrm{U} / \mathrm{mg}$ ). However, for the application of lysozyme in food industry, the use of partially purified lysozyme preparations obtained by cheaper and faster methods would be economically more feasible. For this reason, some fast partial purification procedures have recently been developed based on the precipitation of lysozyme or nonlysozyme protein impurities (Chang et al., 2000; Shin, Rodil, \& Vera, 2003).

Besides incorporation of antimicrobial agents, incorporation of antioxidants into packaging materials has also become very popular since oxidation is a major problem affecting the food quality. Currently, the most frequently used antioxidants in functional packaging are butylated hydroxyanisol (BHA) and butylated hydroxytoluene (BHT) (Rajalakshmi \& Narasimhan, 1996). Although these synthetic antioxidants can effectively be used in active packaging, there are significant concerns related to their toxicological aspects (Madhavi, Singhal, \& Kulkarni, 1996; Vermeiren, Devlieghere, van Beest, de Kruijf, \& Debevere, 1999). Thus, extensive research has been conducted to adopt some natural antioxidants such as phenolic compounds, vitamins $\mathrm{E}$ and $\mathrm{C}$ in place of synthetic antioxidants used in functional packaging (Moore et al., 2003; Vermeiren et al., 1999; Wu, Weller, Hamouz, Cuppett, \& Schnepf, 2001). Some inherently antioxidant protein based films have also been developed from whey proteins (Le Tien, Vachon, Mateescu, \& Lacroix, 2001). Similar to biopreservatives and edible packaging materials, the natural antioxidants are also readily accepted by the consumers and they are not considered as chemicals.

Recently, we have used partially purified lysozyme in antimicrobial packaging (Mecitoğlu et al., 2006). The partially purified lysozyme obtained by removal of the egg white proteins other than the lysozyme by ethanol precipitation was very stable and lost almost no activity in lyophilized form or in cast edible zein films stored at -18 and $4{ }^{\circ} \mathrm{C}$ for up to 8 and 4 months, respectively. The activity of lyophilized partially purified enzyme was not as high as pure commercial enzymes and changed between 2900 and $3351 \mathrm{U} / \mathrm{mg}$. However, the activation of partially purified lysozyme in zein films between $32 \%$ and $215 \%$ brought the advantage of obtaining antimicrobial effect on different bacteria including gram-negative ones when the films were supplemented with disodium EDTA (Mecitoğlu et al.,
2006). The only disadvantage of using partially purified lysozyme is the nonhomogenous distribution of the hydrophilic enzyme preparation in hydrophobic zein films at high concentrations. This problem may partially be overcome by applying extensive mixing and dispersion of film preparation solutions before film casting. However, it is also possible to incorporate lysozyme into films with some other proteins having emulsifying activity and distribute lysozyme in films more homogenously. In this study, the partially purified lysozyme was incorporated into zein films in combination with chickpea albumin extracts (CPAE) or bovine serum albumin (BSA). The films were also supplemented with disodium EDTA $2 \mathrm{H}_{2} \mathrm{O}$ to increase their antimicrobial activity against gram-negative bacteria. In the literature, the antioxidant activities of different legume albumins and human and bovine serum albumins have been well documented (Aime et al., 2003; Fukuzawa et al., 2005; Kouoh et al., 1999; Okada \& Okada, 1998; Wolosiak \& Klepacka, 2002). The presence of emulsifying activity in animal and plant origin albumins has also been reported by different workers (Al-Malah, Azzam, \& Omari, 2000; Burnett et al., 2002; Pearce \& Kinsella, 1978; Tong, Sasaki, McClements, \& Decker, 2000). Thus, this study aims increasing of the distribution of lysozyme and other ingredients in zein films and improvement of antimicrobial and antioxidant activity of the films.

\section{Materials and methods}

\subsection{Materials}

Corn zein, Bovine serum albumin (BSA, Fraction-V), Micrococcus lysodeikticus, dialysis tubes (12000 MW, prepared as described in the product manual) insoluble PVPP (polyvinylpolypyrrolidone) and ABTS (2,2-azino-bis-(3ethylbenz-thiazoline-6-sulfonic acid)) were purchased from Sigma Chem. Co. (St. Louis, MO, USA). Ascorbic acid and glycerol were purchased from Merck (Darmstadt, Germany). Disodium EDTA $\cdot 2 \mathrm{H}_{2} \mathrm{O}$ (ethylenediaminetetraacetate dihydrate) was purchased form Riedel-de haën (Sigma-Aldrich Laborchemikalien, Seelze, Germany). Fresh hen eggs used in production of lysozyme were obtained from a supermarket in İzmir (Turkey).

\subsection{Preparation of partially purified lysozyme}

Lysozyme was produced by slightly modifying the partial purification step given in Jiang, Wang, Chang, and Chang (2001). Briefly, the egg whites separated carefully without disturbing the egg yolks were first diluted with two volumes of $0.05 \mathrm{M} \mathrm{NaCl}$ solution. To precipitate the egg white proteins other than the lysozyme, the $\mathrm{pH}$ of this mixture was set to 4.0 by carefully adding several drops of $1 \mathrm{~N}$ acetic acid and it was diluted with equal volume of $60 \%$ $(\mathrm{v} / \mathrm{v})$ ethanol. After $6 \mathrm{~h}$ incubation at room temperature in presence of $30 \%$ ethanol, the mixture was centrifuged at $15000 \times \mathrm{g}$ for $15 \mathrm{~min}$ at $4^{\circ} \mathrm{C}$ and the precipitate was 
discarded. The supernatant containing lysozyme was first dialyzed for $21 \mathrm{~h}$ at $4^{\circ} \mathrm{C}$ by three changes of $2000 \mathrm{~mL}$ distilled water and then lyophilized by using a freeze drier (Labconco, FreeZone, 61, Kansas City, MO, USA) working between -44 and $-47^{\circ} \mathrm{C}$ collector temperature and $50 \times 10^{-3}$ and $100 \times 10^{-3}$ mbar vacuum. The sample container volume was two to three times the sample volume. The lyophilized enzymes used in film making were stored at $-18^{\circ} \mathrm{C}$ and their activities were determined as $\mathrm{U} / \mathrm{mg}$ before each film preparation.

\subsection{Preparation of chickpea albumin extract}

To prepare albumin extracts, $50 \mathrm{~g}$ of chickpeas were put into a flask containing distilled water and thermally processed at $121{ }^{\circ} \mathrm{C}$ for $20 \mathrm{~min}$ to inactivate microbial contaminants, antinutrients and oxidative enzymes. The samples were then processed immediately to acetone powder to remove lipids and phenolic compounds. For the preparation of acetone powders, the thermally processed chickpeas were homogenized in a Waring blender for $3 \mathrm{~min}$ with $200 \mathrm{~mL}$ cold acetone. The slurry obtained was filtered under vacuum from Buchner funnel containing a Whatman No:1 filter paper and the solid residue remained on the filter paper was collected. The homogenization with $200 \mathrm{~mL}$ cold acetone and filtration were then repeated for two more times for the collected residue and the obtained powder, left overnight to evaporate the acetone, was stored at $-18^{\circ} \mathrm{C}$ until used for protein extraction.

To prepare the albumin extracts acetone powders were extracted by minor modification of the method described by Genovese and Lajolo (1998). Briefly, $20 \mathrm{~g}$ acetone powder, $0.5 \mathrm{~g}$ insoluble PVPP (used to absorb residual phenolic compounds) and $180 \mathrm{ml}$ distilled water were mixed and extracted with a magnetic stirrer for $2 \mathrm{~h}$ at room temperature. The extract was then filtrated from a cheese-cloth (four layers) to collect the filtrate and the cake was discharged. The filtrate was then centrifuged at $15000 \times g$ for $30 \mathrm{~min}$ at $4{ }^{\circ} \mathrm{C}$ and the supernatant was dialyzed for $72 \mathrm{~h}$ $(48 \mathrm{~h}$ against $5 \times 2 \mathrm{~L}$ distilled water and $24 \mathrm{~h}$ against $3 \times 2 \mathrm{~L}$ deionized water) at $4{ }^{\circ} \mathrm{C}$. After dialysis, the extract was clarified by further centrifugation at $4500 \times g$ for $15 \mathrm{~min}$ at $4{ }^{\circ} \mathrm{C}$ and lyophilized and stored at $-18^{\circ} \mathrm{C}$ until it was used in film making. The water soluble protein content of lyophilized CPAE prepared by this method is almost $51 \%$.

\subsection{Film making}

Zein films were produced as described in Padgett et al. (1998). Briefly, $1.4 \mathrm{~g}$ corn zein was dissolved with $8.1 \mathrm{~mL}$ of ethanol $(97 \%)$ by mixing slowly with a magnetic stirrer for $25 \mathrm{~min}$. Glycerol $(0.39 \mathrm{~mL})$ was then added to the medium and the temperature of the mixture was increased until it started to boil. The mixing was then ceased and the film solution was boiled for $5 \mathrm{~min}$. After cooling to room temperature, different amounts of lysozyme, CPAE, BSA or disodium EDTA $\cdot 2 \mathrm{H}_{2} \mathrm{O}$ were added to the mixture to achieve the final concentration of $1400-2800 \mathrm{U} / \mathrm{cm}^{2}$ (479$958 \mu \mathrm{g} / \mathrm{cm}^{2}$ ) lysozyme, 530 or $1060 \mu \mathrm{g} / \mathrm{cm}^{2}$ CPAE or BSA, or 277 or $310 \mu \mathrm{g} / \mathrm{cm}^{2}$ disodium EDTA $\cdot 2 \mathrm{H}_{2} \mathrm{O}$ in dried films, respectively. The mixture was further stirred for $25 \mathrm{~min}$ and $4.3 \mathrm{~g}$ of it was spread evenly onto a $8.5 \times 8.5 \mathrm{~cm}$ glass plate cleaned with ethanol. The plates were dried at room temperature for $24 \mathrm{~h}$. The films were then peeled from the glass plates carefully and $6 \times 6 \mathrm{~cm}$ pieces cut from their middle were used in all tests. The average thicknesses of different films obtained by this procedure changed between 0.15 and $0.18 \mathrm{~mm}$ (almost 10 measurements were conducted at different points of each kind of film with a micrometer).

\subsection{Lysozyme activity}

The activity of lysozyme was determined spectrophotometrically at $660 \mathrm{~nm}$ by using a Shimadzu (Model 2450, Japan) spectrophotometer equipped with a constant temperature cell holder working at $30^{\circ} \mathrm{C}$. The reaction mixture was prepared by mixing $2.3 \mathrm{~mL} M$. lysodeikticus cell suspension $\left(\right.$ at $30^{\circ} \mathrm{C}$ ) prepared $0.26 \mathrm{mg} / \mathrm{mL}$ in $0.05 \mathrm{M}$ Na-phosphate buffer at $\mathrm{pH} 7.0$ and $0.2 \mathrm{~mL}$ release test sample (at $30^{\circ} \mathrm{C}$ ). The reduction in absorbance was monitored for $5 \mathrm{~min}$ and enzyme activity was calculated from the slope of the initial linear portion of absorbance vs. time curve. The enzyme activity was expressed as unit or percent initial activity. One unit was 0.001 change in absorbance in $1 \mathrm{~min}$.

\subsection{Antioxidant activity}

The antioxidant activity was determined by mixing $0.2 \mathrm{~mL}$ of release test sample and $1.9 \mathrm{~mL}$ ABTS* free radical solution prepared and diluted with phosphate buffer saline (PBS) as described by Re et al. (1999). The inhibition of ABTS radical was monitored at $734 \mathrm{~nm}$ and $30^{\circ} \mathrm{C}$ and the percent inhibition of this radical at the end of $3 \mathrm{~min}$ was converted to vitamin $\mathrm{C}$ equivalent by using the standard curve formed by vitamin $\mathrm{C}$ under the same assay conditions.

\subsection{Monitoring of lysozyme activity during release tests}

The release tests were conducted in a refrigerated incubator (126 L, Sanyo Model MIR-153, Japan) at $4{ }^{\circ} \mathrm{C}$. The films $(6 \times 6 \mathrm{~cm})$ were placed in glass petri dishes $(10 \mathrm{~cm}$ in diameter) containing $50 \mathrm{~mL}$ distilled water $\left(4^{\circ} \mathrm{C}\right)$. The petri dishes were then covered with nylon stretch films and their glass lids and incubated for $1800 \mathrm{~min}$ with continuous stirring at $200 \mathrm{rpm}$ with a magnetic stirrer $(2 \mathrm{~mm}$ long teflon coated rod). The lysozyme activity released from films was monitored by taking $0.6 \mathrm{~mL}$ aliquots from the release test solution at different time intervals and conducting activity measurements for three times by using $0.2 \mathrm{~mL}$ of the taken aliquot in a single measurement. The activity was expressed as total units released per $\mathrm{cm}^{2}$ of the films $\left(\mathrm{U} / \mathrm{cm}^{2}\right)$ for a given time period ( $\mathrm{min}$ ). All calculations were corrected by considering the total activity removed during sampling. The monitoring of enzyme release was continued until the activity 
increase in release test solutions ended and a slight reduction in activity initiated. The release rates were calculated from the slopes of the best fit curves of initial portions of activity released $v s$. time curves as $\mathrm{U} / \mathrm{cm}^{2} / \mathrm{min}$. The total lysozyme activity released from a film was determined by considering the maximum enzyme activity released from the film. The percentage of activity recovered from a film in a release test was determined from the ratio of the maximum activity released and the incorporated activity, calculated by considering the activity and amount of partially purified lysozyme added to film making solutions.

\subsection{Monitoring of antioxidant activity during release tests}

To monitor the released antioxidant activity from zein films, release tests were conducted at $4^{\circ} \mathrm{C}$ for $1800 \mathrm{~min}$ as described in lysozyme release tests. The antioxidant activity released from films was monitored by taking $0.6 \mathrm{~mL}$ aliquots from the release test solution at different time intervals and conducting antioxidant activity measurements for three times by using $0.2 \mathrm{~mL}$ of the taken aliquot in a single measurement. The antioxidant activity formed in the $3 \mathrm{~min}$ test was expressed as total vitamin $\mathrm{C}$ equivalent released per $\mathrm{cm}^{2}$ of the films ( $\mathrm{nmol}$ vitamin $\mathrm{C} / \mathrm{cm}^{2}$ ) for a given time period ( $\mathrm{min}$ ). All calculations were corrected by considering the total antioxidant activity removed during sampling. The release rates were calculated from the slopes of the best fit curves of initial portions of antioxidant activity released vs. time curves as $\mathrm{nmol}$ vitamin $\mathrm{C} / \mathrm{cm}^{2} / \mathrm{min}$. The total antioxidant activity released from a film was determined by considering the maximum antioxidant activity released from the film.

\subsection{Determination of immobilized lysozyme activity retained at film surfaces}

In this study, no further increase in lysozyme activity was detected at the end of the release test which lasted for $1800 \mathrm{~min}$. Thus, the enzyme retained in zein films after release test was designated as immobilized enzyme. To determine the immobilized enzyme activity, the films $(6 \times 6 \mathrm{~cm})$ obtained from release tests last for $1800 \mathrm{~min}$ were placed into glass petri dishes containing $25 \mathrm{~mL} \mathrm{M}$. lysodeikticus solution (at $30^{\circ} \mathrm{C}$ ) prepared $0.26 \mathrm{mg} / \mathrm{mL}$ in $0.05 \mathrm{M}$ Na-phosphate buffer at $\mathrm{pH}$ 7.0. The petri dishes were kept in an incubator at $30^{\circ} \mathrm{C}$ and their contents' absorbance at $660 \mathrm{~nm}$ was monitored periodically. The lysozyme activity of the films were determined from the slopes of the initial linear portions of absorbance vs. time curve and given as $\mathrm{U} / \mathrm{cm}^{2}$.

\subsection{Determination of immobilized antioxidant activity retained at film surfaces}

For the determination of their retained antioxidant activity after $1800 \mathrm{~min}$ release test, the films were transferred to glass petri dishes containing $25 \mathrm{~mL}$ ABTS* free radical solution at $30^{\circ} \mathrm{C}$. The inhibition of ABTS radical was monitored at $734 \mathrm{~nm}$ at $30^{\circ} \mathrm{C}$ and the antioxidant activity was calculated by determination of the vitamin $\mathrm{C}$ equivalent of antioxidant activity formed in $10 \mathrm{~min} / \mathrm{cm}^{2}$ of the films (nmol vitamin $\mathrm{C} / \mathrm{cm}^{2}$ ). The standard curve was formed by vitamin $\mathrm{C}$ under the same assay conditions.

\subsection{Test of film antimicrobial activity}

Test of antimicrobial activity was conducted by using Bacillus subtilis (ATCC 6633) and Escherichia coli (ATCC 53868) as test microorganisms. The overnight cultures were prepared in nutrient broth and all incubations were conducted at $37^{\circ} \mathrm{C}$. For antimicrobial tests 20 discs $(0.9 \mathrm{~cm}$ in diameter) were prepared from $6 \times 6 \mathrm{~cm}$ films by a cork borer under aseptic conditions. The cutting was performed carefully to obtain samples from all film surface and 12 of the obtained discs were selected randomly and used in antimicrobial tests. During tests, 4 discs were placed into each petri dish. The discs were placed carefully onto petri dishes containing nutrient agar on which $0.1 \mathrm{~mL}$ culture was spread. The petri dishes were incubated for $24 \mathrm{~h}$ and $48 \mathrm{~h}$ at $37^{\circ} \mathrm{C}$ and the area of the fully formed zones (ffz) observed was determined by measuring the zone diameter with a caliper. The zones with diameters $\leqslant 1.1 \mathrm{~cm}$ and zones formed on only one side of the discs were designated partially formed zones (pfz) and their number was reported. The number of no zone formation (nz) was also counted and reported.

\subsection{Protein content}

In this study the protein contents were determined according to Lowry procedure by using bovine serum albumin as standard (Harris, 1987).

\subsection{Photographs of films}

The surface photographs of the films were obtained with a professional digital camera (Olympus optical Co. Ltd., Japan, 5 MP, Model C5050). The magnified surface and cross-section photographs of the films were obtained with a scanning electron microscope (SEM) (Philips XL 30S FEG, FEI Company, Eindhoven, Netherlands) in Center for Materials Research in Izmir Institute of Technology, İzmir, Turkey.

\section{Results and discussion}

\subsection{Distribution of ingredients in zein films}

The partially purified lysozyme preparation used in this study is mainly hydrophilic. Thus, this limited the solubilization and homogenous distribution of lysozyme and formed some hydrophilic, light yellow colored and semitransparent protein aggregates in hydrophobic zein films (Fig. 1A and B). The hydrophilic protein aggregates rich in 


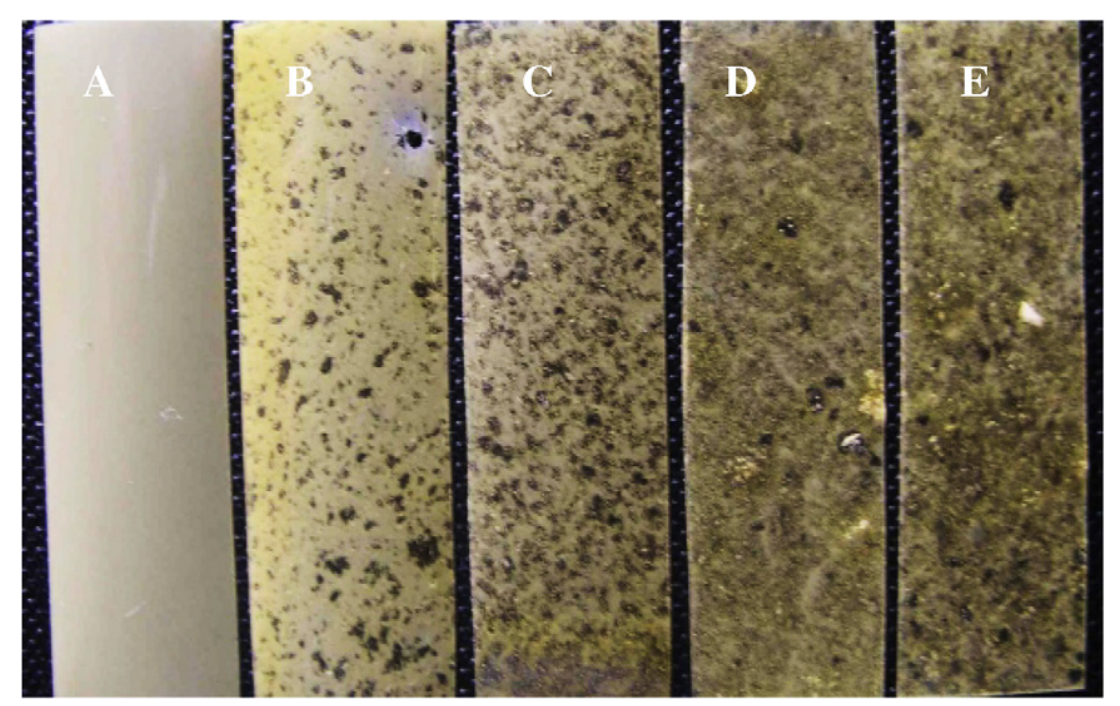

Fig. 1. Photographs of different zein films (Film contents: A, control film; B, $479 \mu \mathrm{g} / \mathrm{cm}^{2}$ lysozyme; C, $479 \mu \mathrm{g} / \mathrm{cm}^{2}$ lysozyme $+530 \mu \mathrm{g} / \mathrm{cm}^{2} \mathrm{CPAE} ; \mathrm{D}, 957 \mu \mathrm{g} /$ $\mathrm{cm}^{2}$ lysozyme $+530 \mu \mathrm{g} / \mathrm{cm}^{2}$ CPAE; E, $479 \mu \mathrm{g} / \mathrm{cm}^{2}$ lysozyme $+1060 \mu \mathrm{g} / \mathrm{cm}^{2}$ CPAE. The background was black to make the light yellow semi-transparent protein aggregates visible.) (For interpretation of the references in color in this figure legend, the reader is referred to the web version of this article.).

lysozyme caused the release of enzyme from the zein films very rapidly when they were wetted (Mecitoğlu et al., 2006). The fast release of an antimicrobial agent from a film is undesirable since this causes the diffusion of released agent at the food surface to interior parts of the food and lets the most risky food surface unprotected against the development of pathogenic contaminants or spoilage microorganisms (Appendini \& Hotchkiss, 2002; Han, 2000). As seen in Fig. 1C, the incorporation of $479 \mu \mathrm{g} / \mathrm{cm}^{2}$ lysozyme preparation into zein films with $530 \mathrm{mg} / \mathrm{cm}^{2}$ CPAE increased the number of protein aggregates in zein films significantly. However, this time the formed many aggregates were mostly small sized and their distribution in zein films is homogenous. On the other hand, at higher lysozyme or CPAE concentrations the zein films became more transparent and the hydrophilic ingredients distributed in films homogenously became major film components as zein (Fig. 1D and E). It seems that an emulsion was formed among CPAE, partially purified lysozyme and zein proteins at high lysozyme or CPAE concentrations.

The distribution of disodium EDTA $2 \mathrm{H}_{2} \mathrm{O}$ in films is also very interesting. In zein films incorporated only with disodium EDTA $2 \mathrm{H}_{2} \mathrm{O}$, the chemical could not be solubilized and it was observed as crystals distributed heterogeneously at different film locations (photographs were not given). However, when disodium EDTA $\cdot 2 \mathrm{H}_{2} \mathrm{O}$ was incorporated with lysozyme, these crystals were hardly observed since they solubilized in the hydrophilic lysozyme aggregates formed in the zein films. The disodium EDTA $2 \mathrm{H}_{2} \mathrm{O}$ solubilized also in films incorporated with lysozyme and CPAE. Thus, it appears that the distribution and solubility of this ingredient in zein films depend highly on existence of hydrophilic proteins.

The increased distribution of partially purified lysozyme aggregates in zein films can also be observed from the SEM photographs of film cross-sections. As seen in Fig. 2A and
$\mathrm{B}$, the incorporation of $310 \mu \mathrm{g} / \mathrm{cm}^{2}$ lysozyme preparation caused the formation of globular protein aggregates at different film locations. The incorporation of $310 \mu \mathrm{g} / \mathrm{cm}^{2}$ lysozyme with $310 \mu \mathrm{g} / \mathrm{cm}^{2} \mathrm{CPAE}$, on the other hand, caused the distribution of globular protein aggregates in different parts of the films (Fig. 2C). The SEM photographs of film surfaces gave information also about the change of porosity of zein films by incorporation of different proteins. As previously detected also by Padgett et al. (1998) from the SEM surface photographs, the zein films are very porous (Fig. 3A). The incorporation of lysozyme increased the pore size of films significantly (Fig. 3B). The incorporation of lysozyme with CPAE also caused the formation of films having greater pores than the control films (Fig. 3C). However, the number of pores in films incorporated with lysozyme, CPAE and disodium EDTA $\cdot 2 \mathrm{H}_{2} \mathrm{O}$ was greater than the number of pores in zein films incorporated with lysozyme and disodium EDTA $\cdot 2 \mathrm{H}_{2} \mathrm{O}$. Thus, it is likely that the hydrophilic protein content of films effects both the size and number of pores in zein films.

In this study, lysozyme was incorporated into zein films also with BSA to determine the effect of this protein on distribution of lysozyme preparation in the films. However, the use of BSA was not beneficial for the distribution of lysozyme aggregates in zein films since it enlarged the size of hydrophilic protein aggregates and made their distribution in zein films more heterogeneous (photographs were not given).

\subsection{Release of lysozyme from films}

The antimicrobial packaging is generally combined with refrigeration (Labuza \& Breene, 1989). Therefore, the release tests in this study were conducted at $4{ }^{\circ} \mathrm{C}$ (Fig. 4). As seen in Table 1, in zein films incorporated with $2019 \mathrm{U} / \mathrm{cm}^{2}$ lysozyme or $2019 \mathrm{U} / \mathrm{cm}^{2}$ lysozyme and $530 \mu \mathrm{g} / \mathrm{cm}^{2}$ BSA the 


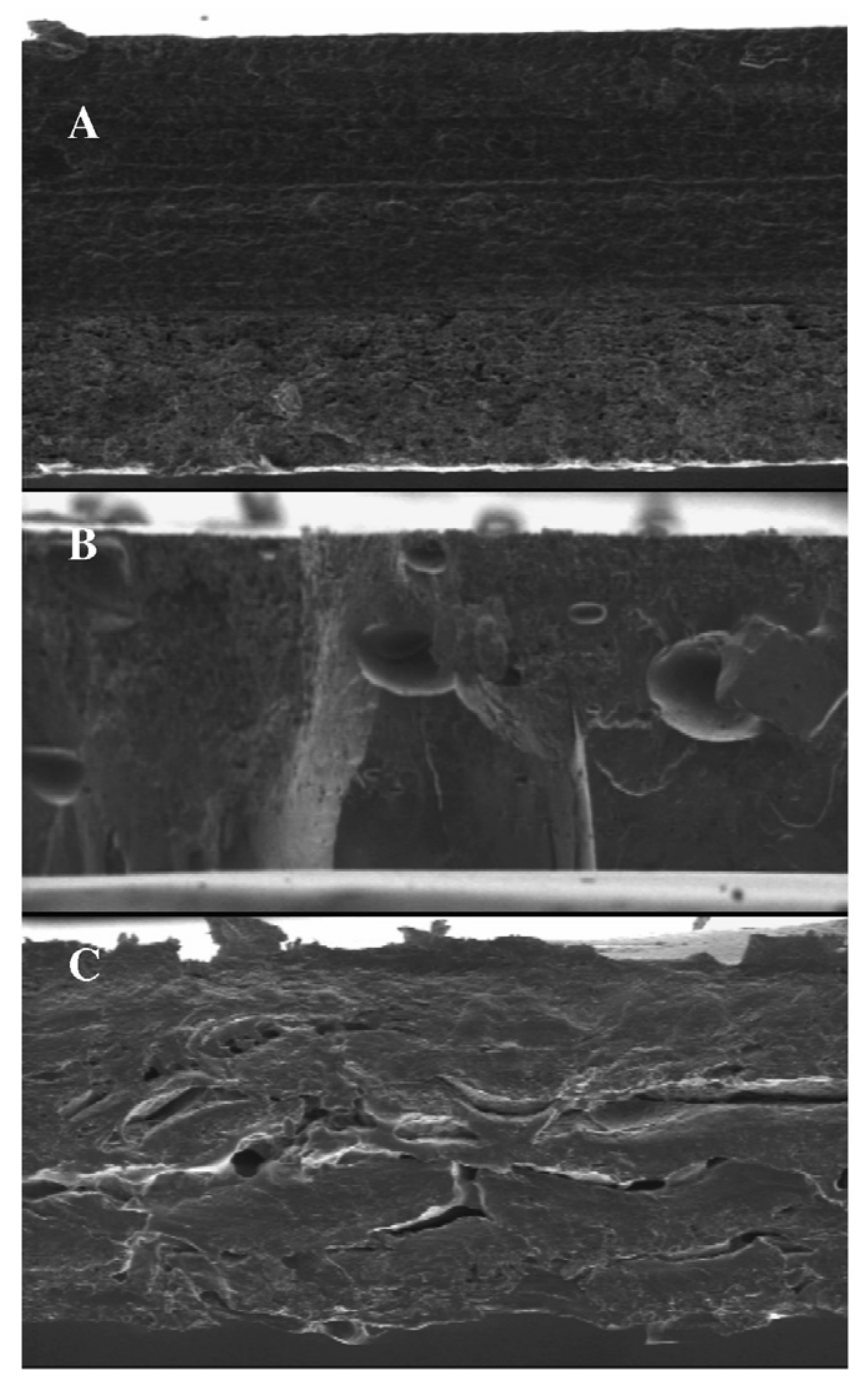

Fig. 2. The cross-section photographs of different zein films obtained by scanning electron microscope $(\mathrm{SEM})$ (magnification $\times 350$; film contents: A, Control film; B, $310 \mu \mathrm{g} / \mathrm{cm}^{2}$ lysozyme $+310 \mu \mathrm{g} / \mathrm{cm}^{2}$ disodium EDTA $\cdot 2 \mathrm{H}_{2} \mathrm{O} ; \mathrm{C}, 310 \mu \mathrm{g} / \mathrm{cm}^{2}$ lysozyme $+310 \mu \mathrm{g} / \mathrm{cm}^{2} \mathrm{CPAE}+310 \mu \mathrm{g} / \mathrm{cm}^{2}$ disodium EDTA $\left.\cdot 2 \mathrm{H}_{2} \mathrm{O}\right)$.

activities released from the films corresponded $227 \%$ and $234 \%$ of activities incorporated into films, respectively. These results confirmed our previous findings that showed the $23-37 \%$ and $32-215 \%$ activation of lysozyme during its partial purification studies and release tests from zein films, respectively (Mecitoğlu et al., 2006). It is thought that the lysozyme activation is related with conformational changes caused by ethanol used both in partial purification of enzyme and preparation of zein films (Mecitoğlu et al., 2006). On the other hand, no activation was observed in zein films incorporated with different concentrations of lysozyme and CPAE. The lysozyme activities released from CPAE containing films were below or close to the level of incorporated lysozyme activities in films. It appears that the better distribution of lysozyme in CPAE containing zein films increased the fraction of enzyme trapped in the internal parts of films. The increased affinity of lysozyme to

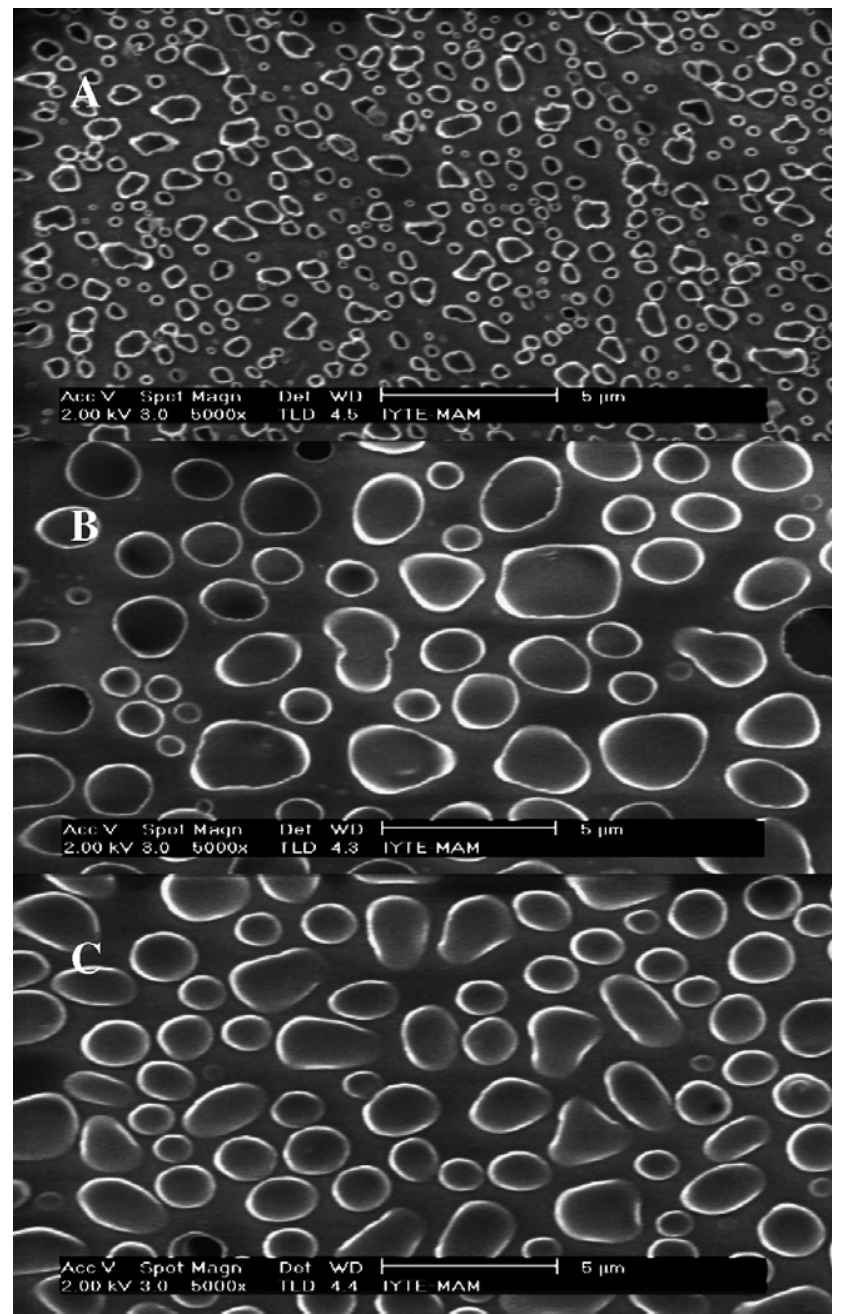

Fig. 3. The surface photographs of different zein films obtained by scanning electron microscope (SEM) (bottom surfaces of films, magnification $\times 5000$; film contents: A, control film; B, $310 \mu \mathrm{g} / \mathrm{cm}^{2}$ lysozyme $+310 \mu \mathrm{g} /$ $\mathrm{cm}^{2}$ disodium EDTA $2 \mathrm{H}_{2} \mathrm{O} ; \mathrm{C}, 310 \mu \mathrm{g} / \mathrm{cm}^{2}$ lysozyme $+310 \mu \mathrm{g} / \mathrm{cm}^{2}$ $\mathrm{CPAE}+310 \mu \mathrm{g} / \mathrm{cm}^{2}$ disodium EDTA $\left.\cdot 2 \mathrm{H}_{2} \mathrm{O}\right)$

films may also be related with the formation of additional ionic interactions and $\mathrm{H}$-bonds among enzyme, zein and CPAE.

The initial release rates of lysozyme from zein films at $4{ }^{\circ} \mathrm{C}$ give more information about the effect of different proteins on lysozyme distribution. As expected, the incorporation of $2019 \mathrm{U} / \mathrm{cm}^{2}$ lysozyme with $530 \mu \mathrm{g} / \mathrm{cm}^{2}$ CPAE reduced the initial release rate of lysozyme almost 1.5-fold. In zein films incorporated with $1400 \mathrm{U} / \mathrm{cm}^{2}$ lysozyme and 530 or $1060 \mu \mathrm{g} / \mathrm{cm}^{2}$ CPEA, the initial release rates were also 1.8- and 3.5-fold lower than that of CPAE free zein films obtained by the same method by incorporating almost the same amount of partially purified lysozyme, respectively (Mecitoğlu et al., 2006). Moreover, in zein films incorporated with $1400 \mathrm{U} / \mathrm{cm}^{2}$ lysozyme, a 2-fold increase in CPAE concentration caused the 2-fold reduction of initial release rate. These results clearly showed the possibility of controlling lysozyme release rates from films by changing the CPAE concentration. However, the reduction of total 


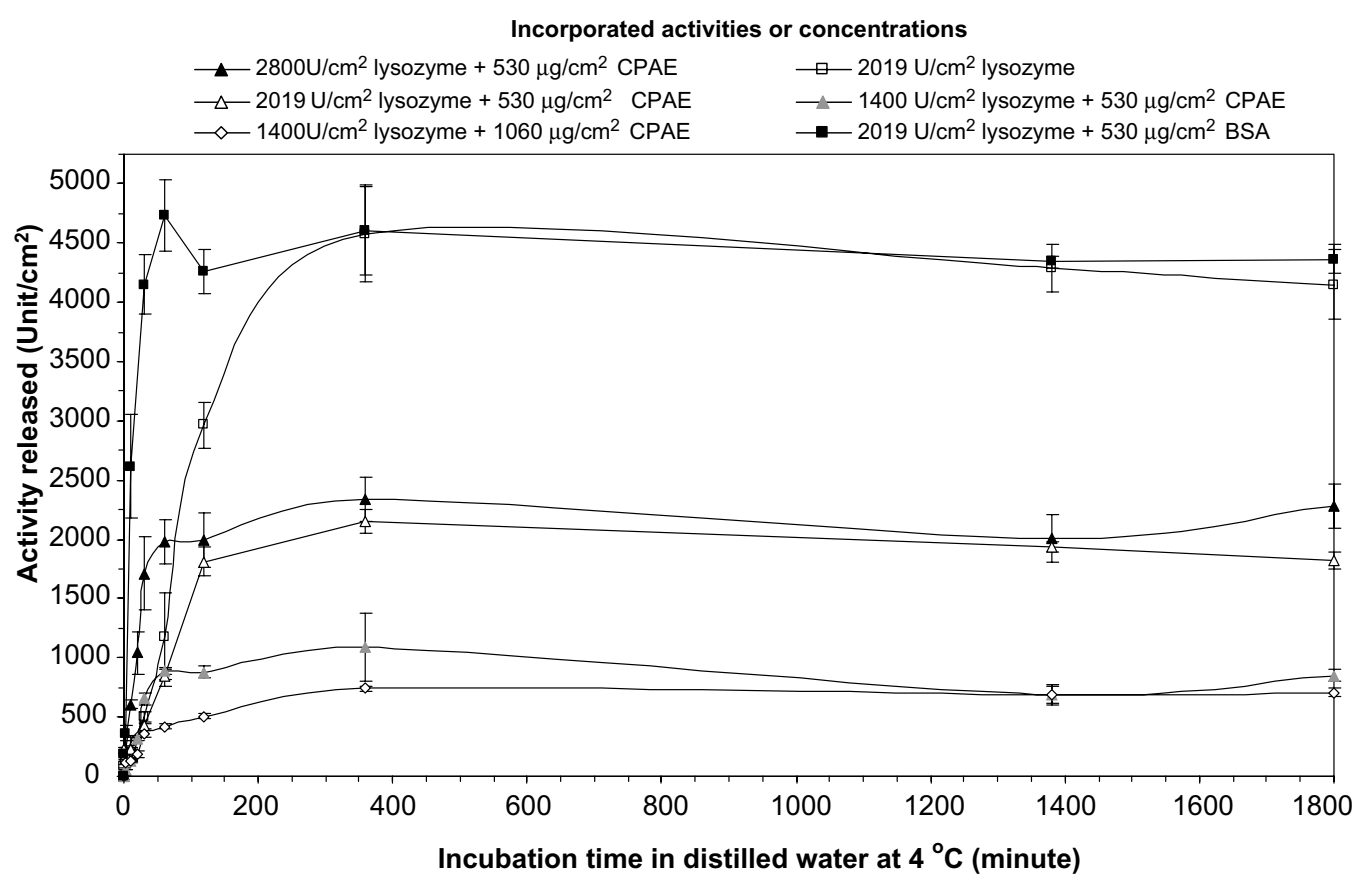

Fig. 4. Release of lysozyme from different zein films in distilled water at $4{ }^{\circ} \mathrm{C}$.

Table 1

Some kinetic parameters related to lysozyme release from zein films at $4{ }^{\circ} \mathrm{C}$

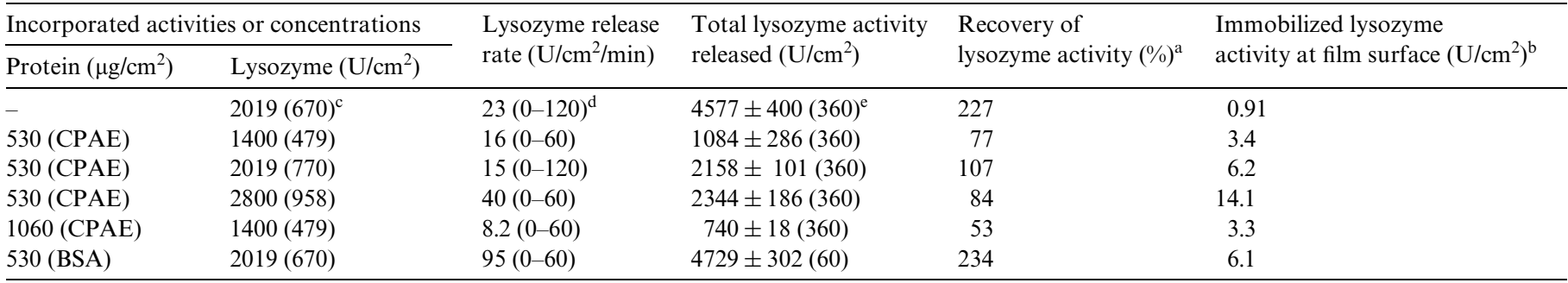

${ }^{a}$ (Total lysozyme activity released/incorporated lysozyme activity) $\times 100$.

${ }^{b}$ Due to different reaction mixture volumes, to compare with soluble lysozyme activities one should multiply these values by the factor of 10 .

c Lysozyme incorporated into films as $\mu \mathrm{g} / \mathrm{cm}^{2}$.

${ }^{d}$ Time periods of data used in best fit.

e Release test periods ( $\mathrm{min})$ to achieve maximum activity released.

lysozyme activity released from the films by almost $30 \%$ after increasing of CPAE concentration of films to $1060 \mu \mathrm{g} /$ $\mathrm{cm}^{2}$ indicated that this is a critical process which needs also the consideration of the sufficiency of total lysozyme activity released from the films to obtain the targeted antimicrobial effect. In contrast, in zein films incorporated with $2019 \mathrm{U} / \mathrm{cm}^{2}$ lysozyme and $530 \mu \mathrm{g} / \mathrm{cm}^{2}$ BSA the release rate of lysozyme was almost 4-fold higher than that of zein films incorporated only with $2019 \mathrm{U} / \mathrm{cm}^{2}$ lysozyme. This result confirmed that the BSA reduced the affinity of lysozyme to zein films by increasing partitioning between hydrophilic lysozyme and hydrophobic zein films.

\subsection{Immobilized lysozyme activity retained at film surfaces}

In antimicrobial packaging, the retention of part of the lysozyme activity in films may be beneficial to maintain the aseptic nature of films and control of microbial growth at the food surfaces. Thus, the level of immobilized lysozyme activity retained at film surfaces after $1800 \mathrm{~min}$ release tests may also be very important. As seen in Fig. 5, the incorporation of $2019 \mathrm{U} / \mathrm{cm}^{2}$ lysozyme with $530 \mu \mathrm{g} / \mathrm{cm}^{2} \mathrm{CPAE}$ or BSA increased the immobilized lysozyme activities of zein films almost the same degree. However, since contributions of these two proteins to distribution of lysozyme in zein films is significantly different, it is hard to conclude that BSA and CPAE incorporated films contained the same amount of bind lysozyme at their film surfaces. It seems that some other factors such as the surface area of films or degree of hydrophilicity which affects the interaction of film surface with water may also be effective on immobilized enzyme activity. In zein films incorporated with $530 \mu \mathrm{g} / \mathrm{cm}^{2}$ CPAE, 1.5-2-fold increase of incorporated lysozyme concentration increased the immobilized lysozyme activity in films 2-4-fold. Thus, it is clear that the surfaces of films incorporated with lysozyme between 1400 and $2800 \mathrm{U} / \mathrm{cm}^{2}$ 
were not fully saturated with the immobilized enzyme. On the other hand, at $1400 \mathrm{U} / \mathrm{cm}^{2}$ lysozyme concentration, the increase of CPAE concentration from 530 to $1060 \mu \mathrm{g} / \mathrm{cm}^{2}$ did not cause a change in immobilized lysozyme activity of zein films. Thus, it seems that the concentration of CPAE alone does not control the level of immobilized lysozyme activity at zein film surfaces.

\subsection{Release of antioxidant activity from films}

The results of the release tests conducted in distilled water at $4{ }^{\circ} \mathrm{C}$ showed that the zein films contained some antioxidant activity inherently (Fig. 6). In zein films incorporated with lysozyme we determined 6-11 times greater protein release than the incorporated lysozyme preparation content of films after 1800 min release tests (results were not given). The zein is insoluble in water and incorporation of lysozyme alone did not contribute to soluble free radical scavenging activity of zein films. Thus, it seems that the commercial zein preparation used in film making contains some minor water soluble protein fractions having antioxidant activity. The antioxidant activities released from zein films incorporated with $2019 \mathrm{U} / \mathrm{cm}^{2}$ lysozyme and 530 or $1060 \mu \mathrm{g} / \mathrm{cm}^{2}$ CPAE were almost $17 \%$ and $25 \%$ higher than those released from control zein films, respectively (Table 2). In contrast, the incorporation of $2019 \mathrm{U} / \mathrm{cm}^{2}$ lysozyme and $530 \mu \mathrm{g} / \mathrm{cm}^{2}$ BSA or $530 \mu \mathrm{g} / \mathrm{cm}^{2}$ BSA alone did not change the antioxidant activity released from zein films considerably. No significant effects of incorporation of BSA, CPAE or lysozyme on release rates of antioxidant activity were also determined. This suggests the minimal interaction between soluble antioxidant fractions and films.

\subsection{Immobilized antioxidant activity retained at film surfaces}

Following $1800 \mathrm{~min}$ release tests, the antioxidant activities retained at film surfaces were also determined (Table 2). As seen in Fig. 7, the control zein film surfaces showed a free radical scavenging activity. The antioxidant activity of zein has also been reported by Chiue, Kusano, and Iwami (1997). These researchers found a strong relationship between the antioxidant activity of zein and its ability to bind and bury unsaturated lipids. Thus, it seems that the zein prevents lipid oxidation also by binding and isolating lipids from free radicals. The retained antioxidant activity at the surface of films incorporated with $2019 \mathrm{U} / \mathrm{cm}^{2}$ lysozyme and $530 \mu \mathrm{g} / \mathrm{cm}^{2}$ BSA was only $22 \%$ higher than that retained at the surface of control films. However, in $2019 \mathrm{U} / \mathrm{cm}^{2}$ lysozyme and $530 \mu \mathrm{g} / \mathrm{cm}^{2}$ CPAE incorporated film surfaces the retained antioxidant activity was almost $84 \%$ higher than that retained at the control film surfaces. Thus, it is clear that the antioxidant components of CPAE contribute more to the immobilized antioxidant activity of the zein films. In the literature, studies related to antioxidant activity of protein based films scarce. Only Le Tien et al. (2001) reported the presence of antioxidant activity of calcium caseinate and whey protein films. The proteins owe their antioxidant activity to their constituent amino acids. For example, the antioxidant activity of tyrosine, phenylalanine,

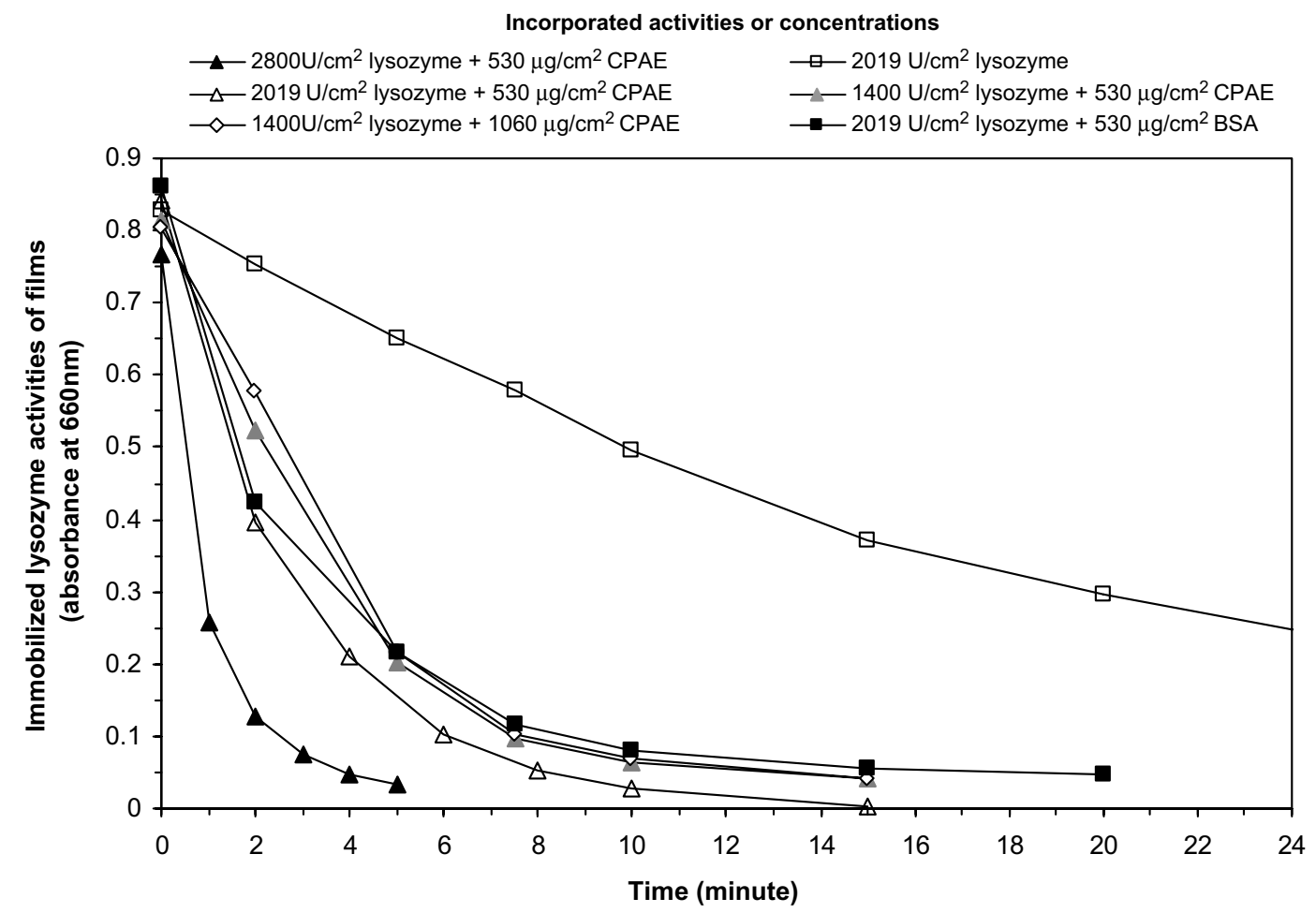

Fig. 5. Immobilized lysozyme activities retained at zein film surfaces determined in M. lysodeicticus solutions after 1800 min release test conducted in distilled water at $4{ }^{\circ} \mathrm{C}$ 


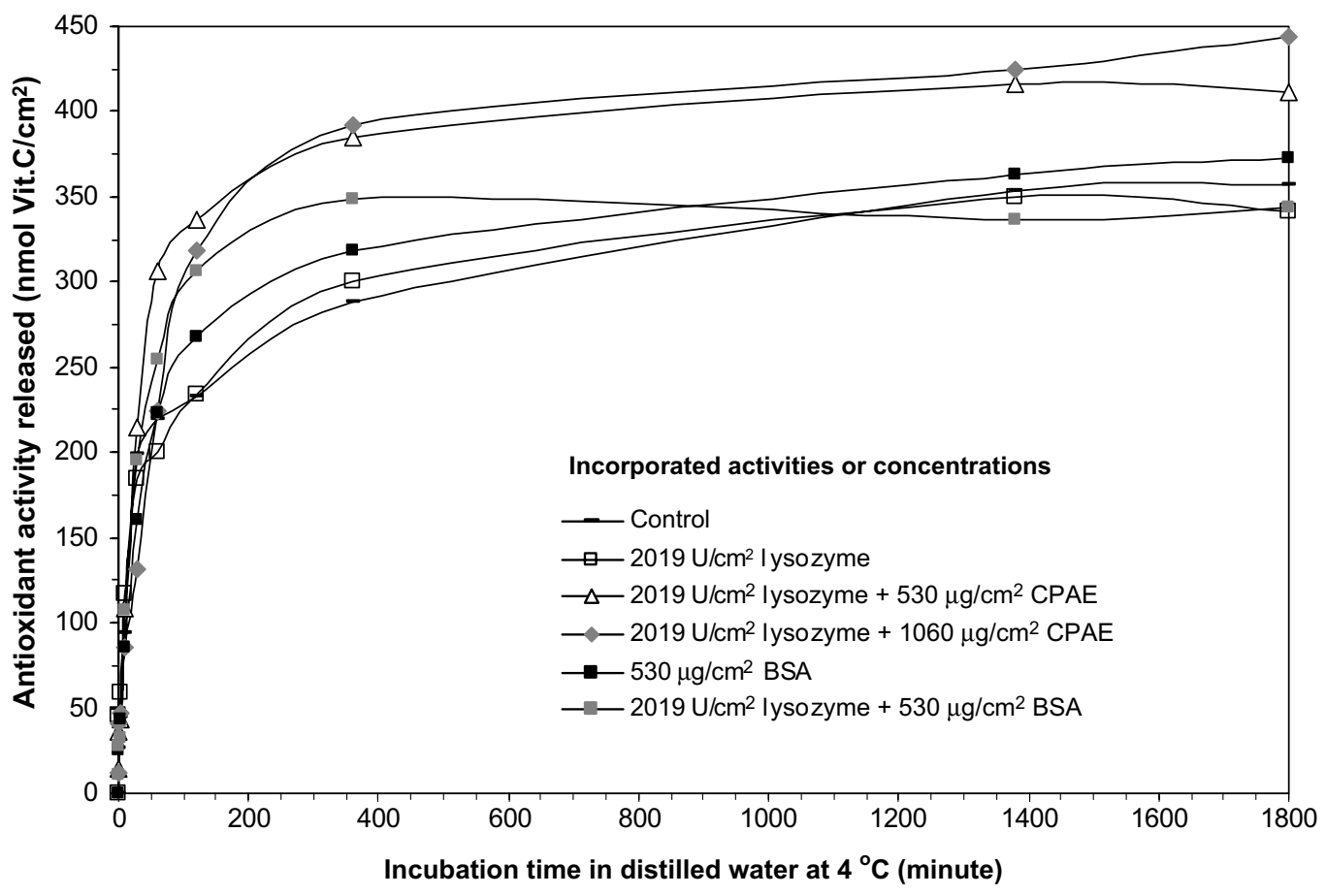

Fig. 6. Release of antioxidant activity from different zein films in distilled water at $4{ }^{\circ} \mathrm{C}$.

Table 2

Some kinetic parameters related to antioxidant activity release from zein films at $4{ }^{\circ} \mathrm{C}$

\begin{tabular}{|c|c|c|c|c|}
\hline \multicolumn{2}{|c|}{ Incorporated activities or concentrations } & \multirow{2}{*}{$\begin{array}{l}\text { Antioxidant activity release } \\
\text { rate }\left(\mathrm{nmol} \text { vit. } \mathrm{C} / \mathrm{cm}^{2} / \mathrm{min}\right)^{\mathrm{a}}\end{array}$} & \multirow{2}{*}{$\begin{array}{l}\text { Total antioxidant activity released } \\
\left(\mathrm{nmol} \text { vit. } \mathrm{C} / \mathrm{cm}^{2}\right)\end{array}$} & \multirow{2}{*}{$\begin{array}{l}\text { Immobilized antioxidant activity } \\
\text { at film surface }\left(\mathrm{nmol} \text { vit. } \mathrm{C} / \mathrm{cm}^{2}\right)^{\mathrm{b}}\end{array}$} \\
\hline Protein $\left(\mu \mathrm{g} / \mathrm{cm}^{2}\right)$ & Lysozyme $\left(\mathrm{U} / \mathrm{cm}^{2}\right)$ & & & \\
\hline- & - & 4.4 & $357 \pm 13(1800)^{\mathrm{c}}$ & 6.8 \\
\hline 530 (CPAE) & $2019(770)$ & 5.7 & $416 \pm 8.6(1380)$ & 12.5 \\
\hline 1060 (CPAE) & $2019(680)$ & 4.0 & $444 \pm 21(1800)$ & nd \\
\hline 530 (BSA) & - & 4.2 & $373 \pm 4.0(1800)$ & nd \\
\hline 530 (BSA) & $2019(670)$ & 4.8 & $349 \pm 6.3(360)$ & 8.3 \\
\hline
\end{tabular}

a Time period of data used in best fit was between 0 and $60 \mathrm{~min}$.

${ }^{\mathrm{b}}$ Due to different reaction mixture volumes, to compare with soluble antioxidant activities one should multiply these values by the factor of 11.9.

${ }^{c}$ Release test periods ( $\mathrm{min}$ ) to achieve maximum antioxidant activity released.

${ }^{\text {d }}$ Lysozyme incorporated into films as $\mu \mathrm{g} / \mathrm{cm}^{2}$.

e nd: not determined.

tryptophan, cysteine is due to their ability to donate protons to free radicals (Hu, McClements, \& Decker, 2003; Je, Park, \& Kim, 2004; Rajapakse, Mendis, Jung, Je, \& Kim, 2005) whereas lysine, arginine, aspartate and glutamate show their antioxidant activity by chelating metal ions (Rajapakse et al., 2005; Saiga, Tanabe, \& Nishumura, 2003). It is reported that the histidine may behave as both a radical scavenger and a metal chelator due to its imidazole ring (Je et al., 2004; Rajapakse et al., 2005).

\subsection{Antimicrobial activity of zein films}

The antimicrobial effects of the obtained films were tested by using E. coli and B. subtilis as test microorganisms (Table 3). The results of antimicrobial tests were in good agreement with our previous findings obtained from film photographs and release tests. For example, in zein films incorporated with only $277 \mu \mathrm{g} / \mathrm{cm}^{2}$ disodium EDTA $\cdot 2 \mathrm{H}_{2} \mathrm{O}$ and tested on $E$. coli, the lack of zone formation in 5 of the 12 discs tested clearly showed the heterogeneous distribution of this chemical in zein films. Also, a reduction was observed in the zone areas of disodium EDTA $2 \mathrm{H}_{2} \mathrm{O}$ incorporated discs when incubation period of petri dishes at $37^{\circ} \mathrm{C}$ was extended from $24 \mathrm{~h}$ to $48 \mathrm{~h}$. The incorporation of $1400 \mathrm{U} / \mathrm{cm}^{2}$ lysozyme with $277 \mu \mathrm{g} / \mathrm{cm}^{2}$ disodium EDTA $\cdot 2 \mathrm{H}_{2} \mathrm{O}$, on the other hand, increased the number of fully formed zones and eliminated no zone formation. However, partially formed zones were observed in 4 of the 12 discs tested on E. coli. In zein films incorporated with $1400 \mathrm{U} / \mathrm{cm}^{2}$ lysozyme, $530 \mu \mathrm{g} / \mathrm{cm}^{2} \mathrm{CPAE}$ and $277 \mu \mathrm{g} / \mathrm{cm}^{2}$ disodium EDTA $\cdot 2 \mathrm{H}_{2} \mathrm{O}$, the zone areas were not changed significantly, but all zones were fully formed and zone areas did not reduce after $48 \mathrm{~h}$ incubation at $37^{\circ} \mathrm{C}$ (Fig. 8). This result clearly showed the contribution of CPAE to homoge- 


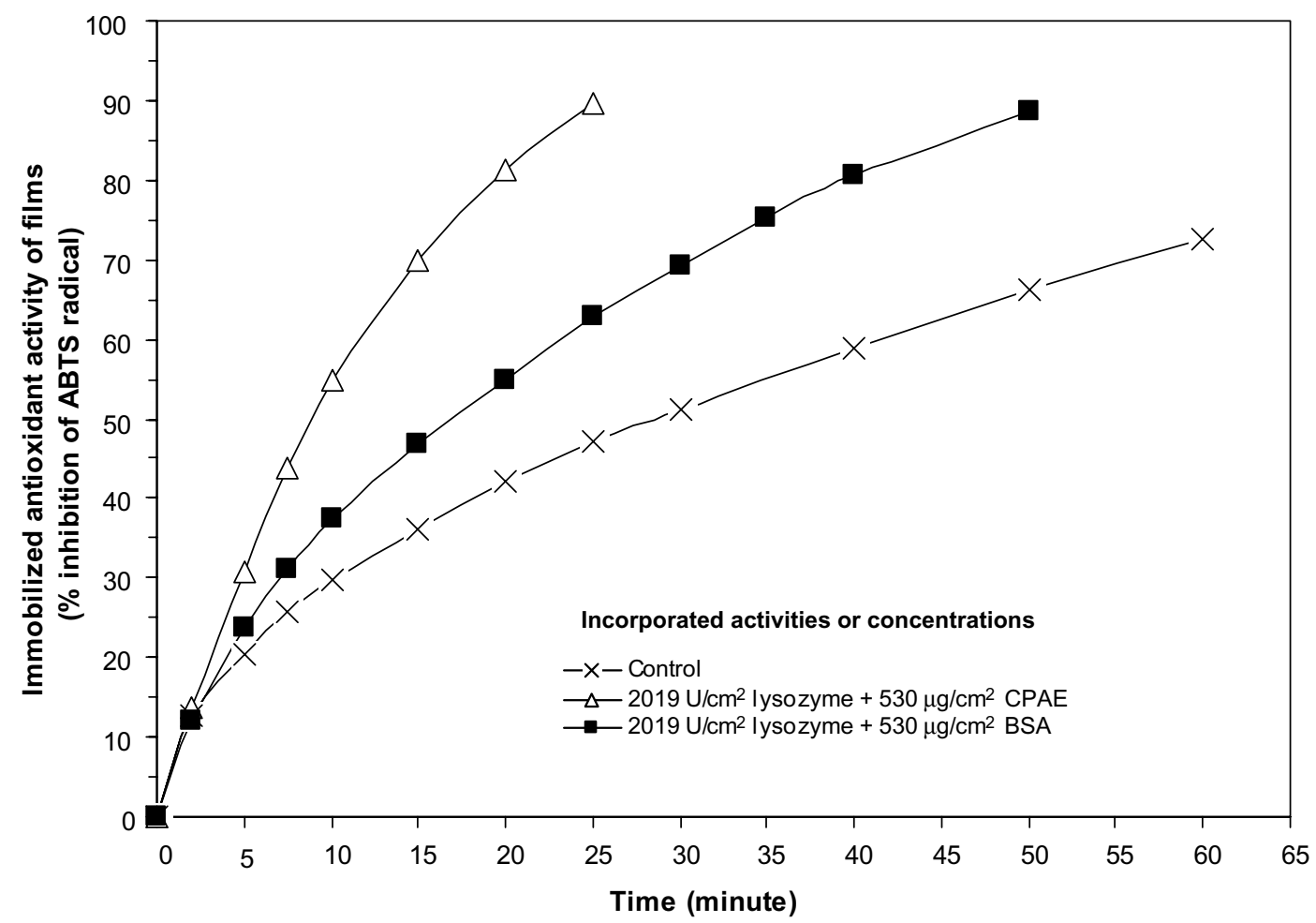

Fig. 7. Immobilized antioxidant activities retained at zein film surfaces determined in ABTS* free radical solutions after 1800 min release test conducted in distilled water at $4{ }^{\circ} \mathrm{C}$.

Table 3

Antimicrobial effects of discs ${ }^{\mathrm{a}}$ obtained from zein films incorporated with partially purified lysozyme, $\mathrm{CPAE}$ and disodium $\mathrm{EDTA} \cdot 2 \mathrm{H}_{2} \mathrm{O}$

\begin{tabular}{|c|c|c|c|c|c|c|}
\hline \multicolumn{3}{|c|}{ Incorporated activities or concentrations } & \multicolumn{2}{|c|}{$\begin{array}{l}\text { Number of fully formed (ffz), partially } \\
\text { formed (pfz) or negative (nz) zones }\end{array}$} & \multicolumn{2}{|c|}{$\begin{array}{l}\text { Average area of fully formed } \\
\text { zones }\left(\mathrm{cm}^{2}\right)\end{array}$} \\
\hline Lysozyme $\left(\mathrm{U} / \mathrm{cm}^{2}\right)$ & $\begin{array}{l}\text { CPAE } \\
\left(\mu \mathrm{g} / \mathrm{cm}^{2}\right)\end{array}$ & $\begin{array}{l}\text { Disodium } \\
\text { EDTA } \cdot 2 \mathrm{H}_{2} \mathrm{O}\left(\mu \mathrm{g} / \mathrm{cm}^{2}\right)\end{array}$ & $24 \mathrm{~h}^{\mathrm{b}}$ & $48 \mathrm{~h}$ & $24 \mathrm{~h}$ & $48 \mathrm{~h}$ \\
\hline \multicolumn{7}{|l|}{ Escherichia coli } \\
\hline- & - & - & $12 \mathrm{nz}$ & $12 \mathrm{nz}$ & 0 & 0 \\
\hline- & - & 277 & $6 \mathrm{ffz} / 1 \mathrm{pfz} / 5 \mathrm{nz}$ & $7 \mathrm{ffz} / 5 \mathrm{nz}$ & $0.75 \pm 0.33$ & $0.61 \pm 0.37$ \\
\hline $1400(479)^{\mathrm{c}}$ & - & 277 & $8 \mathrm{ffz} / 4 \mathrm{pfz}$ & $8 \mathrm{ffz} / 4 \mathrm{pfz}$ & $0.70 \pm 0.26$ & $0.67 \pm 0.28$ \\
\hline $1400(479)$ & 530 & 277 & $12 \mathrm{ffz}$ & $12 \mathrm{ffz}$ & $0.71 \pm 0.47$ & $0.73 \pm 0.39$ \\
\hline $2800(957)$ & 530 & 277 & $9 \mathrm{ffz} / 3 \mathrm{pfz}$ & $8 \mathrm{ffz} / 4 \mathrm{pfz}$ & $0.54 \pm 0.18$ & $0.54 \pm 0.25$ \\
\hline $1400(479)$ & 1060 & 277 & $12 \mathrm{pfz}$ & $12 \mathrm{pfz}$ & - & - \\
\hline \multicolumn{7}{|l|}{ Bacillus subtilis } \\
\hline- & - & - & $12 \mathrm{nz}$ & $12 \mathrm{nz}$ & 0 & 0 \\
\hline 1400 (479) & - & 277 & $12 \mathrm{ffz}$ & $12 \mathrm{ffz}$ & $0.68 \pm 0.38$ & $0.78 \pm 0.46$ \\
\hline $1400(479)$ & 530 & 277 & $12 \mathrm{ffz}$ & $10 \mathrm{ffz} / 2 \mathrm{pfz}$ & $0.54 \pm 0.18$ & $0.54 \pm 0.16$ \\
\hline $2800(957)$ & 530 & 277 & $12 \mathrm{ffz}$ & $12 \mathrm{ffz}$ & $0.58 \pm 0.20$ & $0.63 \pm 0.23$ \\
\hline $1400(479)$ & 1060 & 277 & $8 \mathrm{ffz} / 4 \mathrm{pfz}$ & $8 \mathrm{ffz} / 4 \mathrm{pfz}$ & $0.46 \pm 0.13$ & $0.46 \pm 0.10$ \\
\hline
\end{tabular}

${ }^{a}$ Discs from 1400 and $2800 \mathrm{U} / \mathrm{cm}^{2}$ lysozyme incorporated films contained $896 \mathrm{U}$ (307 $\left.\mu \mathrm{g}\right)$ and $1792 \mathrm{U}$ (612 $\left.\mu \mathrm{g}\right)$ lysozyme, respectively; discs from $277 \mu \mathrm{g} /$ $\mathrm{cm}^{2}$ disodyum EDTA $\cdot 2 \mathrm{H}_{2} \mathrm{O}$ incorporated films contained $177 \mu \mathrm{g}$ disodyum EDTA $\cdot 2 \mathrm{H}_{2} \mathrm{O}$; discs from 530 and $1060 \mu \mathrm{g} / \mathrm{cm}^{2} \mathrm{CPAE}$ extract incorporated films contained 339 and $678 \mu \mathrm{g}$ CPAE, respectively.

${ }^{\mathrm{b}}$ Incubation periods of petri dishes at $37^{\circ} \mathrm{C}$ were $24 \mathrm{~h}$ or $48 \mathrm{~h}$.

${ }^{\mathrm{c}}$ Lysozyme incorporated into films as $\mu \mathrm{g} / \mathrm{cm}^{2}$.

nous distribution of lysozyme in zein films. In contrast, further increase of incorporated lysozyme from $1400 \mathrm{U} / \mathrm{cm}^{2}$ to $2800 \mathrm{U} / \mathrm{cm}^{2}$, while maintaining CPAE concentration at $530 \mu \mathrm{g} / \mathrm{cm}^{2}$, caused the reduction of the areas of fully formed zones and formed some partially formed zones. The released lysozyme activity of $2800 \mathrm{U} / \mathrm{cm}^{2}$ lysozyme and
$530 \mu \mathrm{g} / \mathrm{cm}^{2}$ CPAE incorporated films was almost 2-fold higher than that of $1400 \mathrm{U} / \mathrm{cm}^{2}$ lysozyme and $530 \mu \mathrm{g} / \mathrm{cm}^{2}$ CPAE incorporated films (Table 1). Thus, it seems that the structural changes observed in films at this high lysozyme concentration (see Fig. 1D) caused the trapping of disodium EDTA $\cdot 2 \mathrm{H}_{2} \mathrm{O}$ in the films. On the other hand, the 


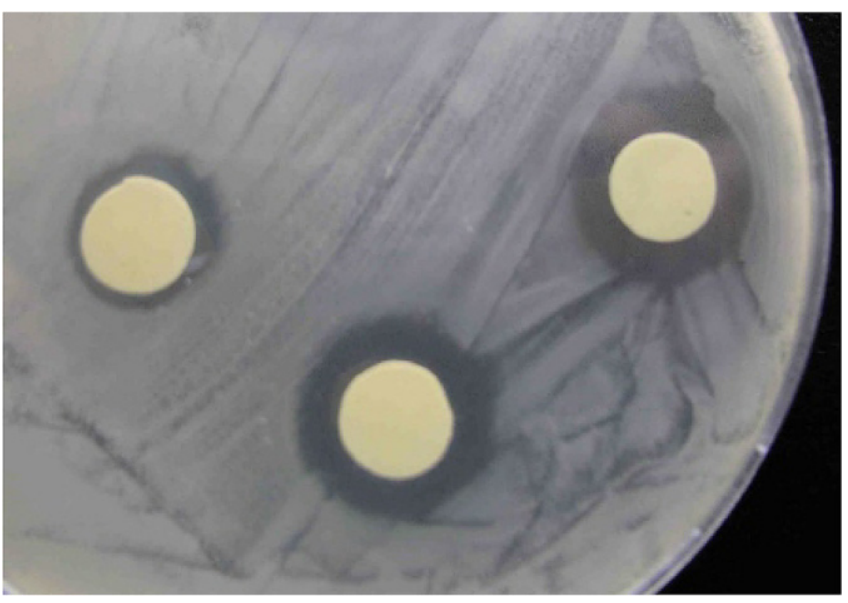

Fig. 8. Antimicrobial effect of zein films on E. coli (disc contents: $896 \mathrm{U}$ $(307 \mu \mathrm{g})$ lysozyme $+339 \mu \mathrm{g} \mathrm{CPAE}+177 \mu \mathrm{g}$ disodium EDTA $\left.\cdot 2 \mathrm{H}_{2} \mathrm{O}\right)$.

increase of CPAE concentration from $530 \mu \mathrm{g} / \mathrm{cm}^{2}$ to $1060 \mu \mathrm{g} / \mathrm{cm}^{2}$, while lysozyme concentration was $1400 \mathrm{U} /$ $\mathrm{cm}^{2}$, turned all fully formed zones to partially formed zones. These results show that too much increase of lysozyme or CPAE concentration changes the film structure and this reduces the amount of lysozyme or disodium EDTA released from the films. However, the formation of partially formed zones on $E$. coli suggested that films incorporated with high concentrations of CPAE may still be used in functional packaging to obtain more limited antimicrobial effect, but higher antioxidant activity at food contact surfaces.

The zein films incorporated with $1400 \mathrm{U} / \mathrm{cm}^{2}$ lysozyme and $277 \mu \mathrm{g} / \mathrm{cm}^{2}$ disodium EDTA $\cdot 2 \mathrm{H}_{2} \mathrm{O}$ were effective also on $B$ subtilis. All zones formed at this concentrations were fully formed and their areas were increased slightly by extending incubation period of petri dishes at $37^{\circ} \mathrm{C}$ from $24 \mathrm{~h}$ to $48 \mathrm{~h}$. The incorporation of 530 or $1060 \mu \mathrm{g} / \mathrm{cm}^{2}$ CPAE with $1400 \mathrm{U} / \mathrm{cm}^{2}$ lysozyme and $277 \mu \mathrm{g} / \mathrm{cm}^{2}$ disodium EDTA $\cdot 2 \mathrm{H}_{2} \mathrm{O}$, on the other hand, reduced the zone areas significantly and turned some fully formed zones to partially formed zones. The reduction in antimicrobial effect of CPAE incorporated films on B. subtilis occurred probably due to the reduction of lysozyme released from the films. However, in zein films incorporated with $530 \mu \mathrm{g} / \mathrm{cm}^{2} \mathrm{CPAE}$ this handicap may partially be overcome by increase of lysozyme concentration from $1400 \mathrm{U} / \mathrm{cm}^{2}$ to $2800 \mathrm{U} / \mathrm{cm}^{2}$.

\section{Conclusions}

In this study, we have developed functional edible films with antimicrobial and antioxidant activity by incorporation of partially purified lysozyme, CPEA and disodium EDTA $\cdot 2 \mathrm{H}_{2} \mathrm{O}$ into zein films. The use of CPAE in combination with lysozyme increases the soluble and immobilized free radical scavenging activity of zein films. The CPAE also improves the distribution of partially purified lysozyme preparation in zein films and this slows down lysozyme release rates of films in distilled water. This study clearly showed the good potential of using partially purified lysozyme in combination with functional protein extracts to improve antioxidant activity and homogeneity and to control release rates of lysozyme from hydrophobic protein based films. Further studies are now continuing in our laboratory to apply developed films on selected foods and show their effects on microbial load and oxidative changes.

\section{Acknowledgements}

This project (MISAG \# 221) was funded by The Scientific and Technical Research Council of Turkey (TÜBITAK). We thank Research Assistant Fatih Y.G. Yener for his assistance during preparation of zein films photographed in SEM.

\section{References}

Aime, S., Digilio, G., Bruno, E., Mainero, V., Baroni, S., \& Fasano, M. (2003). Modulation of the antioxidant activity of HO scavengers by albumin binding: a ${ }^{19}$ F-NMR study. Biochemical and Biophysical Research Communications, 307, 962-966.

Al-Malah, K. I., Azzam, M. O. J., \& Omari, R. M. (2000). Emulsifying properties of BSA in different vegetable oil emulsions using conductivity technique. Food Hydrocolloids, 14, 485-490.

Appendini, P., \& Hotchkiss, J. H. (1997). Immobilization of lysozyme on food contact polymers as potential antimicrobial films. Packaging Technology and Science, 10, 271-279.

Appendini, P., \& Hotchkiss, J. H. (2002). Review of antimicrobial food packaging. Innovative Food Science and Emerging Technologies, 3, 113-126.

Branen, J. K., \& Davidson, P. M. (2004). Enhancement of nisin, lysozyme, and monolaurin antimicrobial activities by ethylenediaminetetraacetic acid and lactoferrin. International Journal of Food Microbiology, 90, 63-74.

Buonocore, G. G., Del Nobile, M. A., Panizza, A., Bove, S., Battaglia, G., \& Nicolais, L. (2003). Modeling the lysozyme release kinetics from antimicrobial films intended for food packaging applications. Journal of Food Science, 68, 1365-1370.

Burnett, G., Rigby, N. M., Mills, E. N. C., Belton, P. S., Fido, R. J., Tatham, A. S., et al. (2002). Characterization of the emulsification properties of $2 \mathrm{~S}$ albumins from sunflower seed. Journal of Colloid and Interface Science, 247, 177-185.

Cha, D. S., Choi, J. H., Chinnan, M. S., \& Park, H. J. (2002). Antimicrobial films based on Na-alginate and $\kappa$-carrageenan. Lebensmittel Wissenschaft und Technologie, 35(8), 715-719.

Chang, H., Yang, C., \& Chang, Y. (2000). Rapid separation of lysozyme from chicken egg white by reductants and thermal treatment. Journal of Agricultural and Food Chemistry, 48(2), 161-164.

Chiue, H., Kusano, T., \& Iwami, K. (1997). Deamidation-induced fragmentation of maize zein, and its linked reduction in fatty acid-binding capacity as well as antioxidative effect. Food Chemistry, 58, 111-117.

De Roever, C. (1998). Microbiological safety evaluations and recommendations on fresh produce. Food Control, 9(6), 321-347.

Fukuzawa, K., Saitoh, Y., Akai, K., Kogure, K., Ueno, S., Tokumura, A., et al. (2005). Antioxidant effect of bovine serum albumin on membrane lipid peroxidation induced by iron chelate and superoxide. Biochimica et Biophysica Acta, 1668, 145-155.

Genovese, M. I., \& Lajolo, F. M. (1998). Influence of naturally acid-soluble proteins from beans (Phaseolus vulgaris L.) on in vitro digestibility determination. Food Chemistry, 62, 315-323.

Han, J. H. (2000). Antimicrobial food packaging. Food Technology, 54(3), $56-65$.

Harris, D. A. (1987). Spectrophotometric assays. In D. A. Harris \& C. L. Bashford (Eds.), Spectrophotometry and spectrofluorometry (pp. 59-60). Oxford: I.R.L. Press. 
Hu, M., McClements, D. J., \& Decker, E. A. (2003). Lipid oxidation in corn oil-in-water emulsions stabilized by casein, whey protein isolate, and soy protein isolate. Journal of Agricultural and Food Chemistry, 51, 1696-1700.

Je, J., Park, P., \& Kim, S. (2004). Antioxidant activity of a peptide isolated from Alaska pollack (Theragra chalcogramma) frame protein hydrolysate. Food Research International, 52, 7842-7845.

Jiang, C. M., Wang, M. C., Chang, W. H., \& Chang, H. M. (2001). Isolation of lysozyme from hen egg albumen by alcohol-insoluble cross-linked pea pod solid ion-exchange chromatography. Journal of Food Science, 66(8), 1089-1092.

Judge, R., Forsythe, E. L., \& Pusey, M. L. (1998). The effect of protein impurities on lysozyme crystal growth. Biotechnology and Bioengineering, 59(6), 776-785.

Kouoh, F., Gressier, B., Luyckx, M., Brunet, C., Dine, T. D., Cazin, M., et al. (1999). Antioxidant properties of albumin: effect on oxidative metabolism of human neutrophil granulocytes. Il Farmaco, 54, 695699.

Labuza, T. P., \& Breene, W. M. (1989). Applications of "active packaging” for improvement of shelf-life and nutritional quality of fresh and extended shelf-life foods. Journal of Food Processing and Preservation, 13, 1-69.

Le Tien, C., Vachon, C., Mateescu, M. A., \& Lacroix, M. (2001). Milk protein coatings prevent oxidative browning of apples and potatoes. Journal of Food Science, 66, 512-516.

Madhavi, D. L., Singhal, R. S., \& Kulkarni, P. R. (1996). Technological aspects of food antioxidants. In D. L. Madhavi, S. S. Deshpande, \& D. K. Salunke (Eds.), Food antioxidants (pp. 159-265). New York: Marcel Dekker Inc..

Mecitoğlu, Ç., Yemenicioğlu, A., Arslanoğlu, A., Elmacı, Z. S., Korel, F., \& Çetin, A. E. (2006). Incorporation of partially purified hen egg white lysozyme into zein films for antimicrobial food packaging. Food Research International, 39, 12-21.

Min, S., Harris, L., \& Krochta, J. M. (2005). Antimicrobial effects of lactoferrin, lysozyme, and the lactoperoxidase system and edible whey protein films incorporating the lactoperoxidase system against Salmonella enterica and Escherichia coli O157:H7. Journal of Food Science, 70, 332-338.

Moore, M. E., Han, I. Y., Acton, J. C., Ogale, A. A., Barmore, C. R., \& Dawson, P. L. (2003). Effects of antioxidants in polyethylene film on fresh beef color. Journal of food Science, 68, 99-104.

Okada, Y., \& Okada, M. (1998). Scavenging effect of water soluble proteins in broad beans on free radicals and active oxygen spices. Journal of Agriculture and Food Chemistry, 46, 401-406.
Padgett, T., Han, I. Y., \& Dawson, P. L. (1998). Incorporation of foodgrade antimicrobial compounds into biodegradable packaging films. Journal of Food Protection, 61(10), 1330-1335.

Park, S. I., Daeschel, M. A., \& Zhao, Y. (2004). Functional properties of antimicrobial lysozyme-chitosan composite films. Journal of Food Science, 69, 215-221.

Pearce, K. N., \& Kinsella, J. E. (1978). Emulsifying properties of proteins: evaluation of a turbidimetric technique. Journal of Agricultural and Food Chemistry, 26(3), 716-723.

Quintavalla, S., \& Vicini, L. (2002). Antimicrobial food packaging in meat industry. Meat Science, 62, 373-380.

Rajalakshmi, D., \& Narasimhan, S. (1996). Food antioxidants: sources and methods of evaluation. In D. L. Madhavi, S. S. Deshpande, \& D. K. Salunke (Eds.), Food antioxidants (pp. 65-157). New York: Marcel Dekker Inc.

Rajapakse, N., Mendis, E., Jung, W., Je, J., \& Kim, S. (2005). Purification of a radical scavenging peptide from fermented mussel sauce and its antioxidant properties. Food Research International, 38, 175-182.

Re, R., Pellegrini, N., Proteggente, A., Pannala, A., Yang, M., \& RiceEvans, C. (1999). Antioxidant activity applying an improved ABTS radical cation decolorization assay. Free Radical Biology and Medicine, 26, 1231-1237.

Saiga, A., Tanabe, S., \& Nishumura, T. (2003). Antioxidant activity of peptides obtained from porcine myofibrillar proteins by protease treatment. Journal of Agricultural and Food Chemistry, 51, 3661-3667.

Shin, Y. O., Rodil, E., \& Vera, J. H. (2003). Selective preparation of lysozyme from egg white using AOT. Journal of Food Science, 68(2), 595-599.

Suppakul, P., Miltz, J., Sonneveld, K., \& Bigger, S. W. (2003). Active packaging technologies with an emphasis on antimicrobial packaging and its applications. Journal of Food Science, 68(2), 408-420.

Tong, L. M., Sasaki, S., McClements, D. J., \& Decker, E. A. (2000). Mechanisms of the antioxidant activity of a high molecular weight fraction of whey. Journal of Agricultural and Food Chemistry, 48, 1473-1478.

Vermeiren, L., Devlieghere, F., van Beest, M., de Kruijf, N., \& Debevere, J. (1999). Developments in the active packaging of foods. Trends in Food Science and Technology, 10, 77-86.

Wolosiak, R., \& Klepacka, M. (2002). Antioxidative properties of albumins in enzymatically catalyzed model systems. Electronic Journal of Polish Agricultural Universities, Series: Food Science and Technology, $5,1 .<$ http://www.eipau.media.pl $>$.

Wu, Y., Weller, C. L., Hamouz, F., Cuppett, S., \& Schnepf, M. (2001). Moisture loss and lipid oxidation for precooked ground-beef patties packaged in edible starch-alginate- based composite films. Journal of Food Science, 65, 486-493. 